\title{
Sistem Penentuan Penyakit Pada Ayam Menggunakan Metode Forward Chaining
}

\author{
Hilda Sanjaya ${ }^{1}$, Tjahjaning Tingastuti ${ }^{2}$, Elkana Lewi Santoso ${ }^{3}$ \\ ${ }^{1}$ Sekolah Tinggi Teknologi Cahaya Surya Kediri \\ ${ }^{2,3}$ Sekolah Tinggi Teknologi Cahaya Surya Kediri \\ E-mail: ${ }^{1}$ hilda_sanjaya@yahoo.co.id \\ ,2mariasurjosuseo@yahoo.com, ${ }^{3}$ elkana@cahayasurya.ac.id
}

\begin{abstract}
Abstrak
Unggas merupakan hewan ternak yang paling banyak diternakkan karena banyak memberikan manfaat dan keuntungan. Seperti halnya dengan hewan ternak lainya, Ayam mempunyai bermacam jenis penyakit. Peternak yang ingin beternak ayam khususnya orang awam terbentur oleh beberapa masalah salah satunya adalah penyakit. Proses diagnosis penyakit diperlukan gejala-gejala yang tampak pada tubuh ayam. Diperlukan keseriusan dan tindakan yang cepat sebelum terlambat dan mengalami kerugian. Sistem yang dibangun ini merupakan sistem pengelolaan pengetahuan yang mudah digunakan dan dinamis. Aplikasi dikembangkan dengan menggunakan bahasa pemrograman PHP dan MySQL sebagai basis data. Metode inferensi yang digunakan adalah Forward Chaining, yaitu proses inferensi yang memulai pencarian dari premis atau data masukan berupa gejala menuju pada konklusi yaitu kesimpulan penyakit yang diderita serta memberikan solusi mengenai saran pengobatan dan pencegahan berdasarkan gejala-gejala yang diamati. Sistem yang dihasilkan mampu melakukan diagnosa terhadap penyakit ayam, dengan melakukan pengujian terhadap sampel.
\end{abstract}

Kata Kunci - Forward Chaining, Sistem Penentuan Penyakit

\begin{abstract}
Poultry is the most farmed livestock because it provides many benefits and benefits. As with other farm animals, Chickens have various types of diseases. Breeders who want to raise chickens, especially the layman is struck by several problems one of which is a disease. The process of diagnosis of the disease required symptoms that appear on the chicken body. It takes seriousness and quick action before it's too late and loses. This built system is an easyto-use and dynamic knowledge management system. The application was developed using PHP and MYSQL programming languages as database. The inference method used is Forward Chaining, namely the inference process that starts the search from the premise or input data in the form of symptoms to the conclusion of the conclusion of the illness suffered as well as providing solutions on treatment and prevention advice based on the symptoms observed. The resulting system is able to make a diagnosis of chicken disease, by testing the sample.
\end{abstract}

Keywords - Forward Chaining, Disease Determination System

\section{PENDAHULUAN}

Kecerdasan buatan merupakan salah satu bidang studi tentang bagaimana membuat komputer pada saat ini dapat melakukan hal-hal yang dilakukan lebih baik oleh manusia [1].. 
Salah satu bidang teknik kecerdasan buatan yang paling diminati adalah sitem pakar (expert system). Sistem pakar merupakan sistem berbasis komputer menggunakan pengetahuan, fakta, dan teknik penalaran dalam memecahkan masalah yang biasanya hanya bisa dilakukan oleh seorang pakar dalam bidang tertentu tersebut [2].

Sistem pakar merupakan bidang ilmu yang penerapannya dapat dipakai di berbagai bidang baik dibidang ilmu kesehatan, sosial, bisnis dan beberapa bidang lainnya. Perkembangan sistem pakar dalam bidang kesehatan, salah satunya dapat diterapkan dalam bidang peternakan terutama peternakan ayam.

Seorang peternak ayam setidaknya harus mempelajari dari berbagai sumber tentang penyakit yang dapat menyerang ayam serta bagaimana menanganinya jika ingin ayam hasil ternaknya itu mempunyai kondisi sehat saat panen tiba, sehingga tidak mengalami kerugian. Permasalahan lainnya adalah biaya konsultasi dengan dokter juga bukan jumlah yang sedikit, dalam hal ini kami ingin membuat sistem penentuan penyakit pada ayam berdasarkan gejala yang timbul untuk dapat membantu memecahkan masalah tersebut.

Metode Forward Chaining merupakan salah satu metode yang banyak dipakai dalam sistem pakar, yaitu metode pencarian atau teknik pelacakan ke depan dimulai dari informasi yang ada dan penggabungan rule untuk menghasilkan suatu kesimpulan atau tujuan [3]. Kemampuan metode Forward Chaining dalam melakukan diagnosa penyakit juga dapat dibuktikan oleh [4]. Gambaran diatas menjadi pertimbangan peneliti dalam membuat sistem penentuan penyakit pada ayam berdasarkan gejala fisik yang timbul. Sebagai upaya dalam mengembangkan cara pemeliharaan dan perawatan ayam melalui sebuah komputer.

\section{FORWARD CHAINING}

Terdapat dua (2) pendekatan untuk mengontrol inferensi dalam sistem pakar berbasis aturan, pelacakan kebelakang (backwardchaining) dan pelacakan kedepan (forwardchaining). Pelacakan kedepan merupakan pendekatan yang didahului oleh data (data-driven). Pelacakan ini dimulai dari informasi masukan, yang selanjutnya akan mencoba menggambarkan kesimpulan. Pelacakan ke depan ini mencari fakta yang sesuai dengan bagian IF dari aturan IF-THEN. Model dari metode Forward Chaning dapat digambarkan melalui gambar 1.

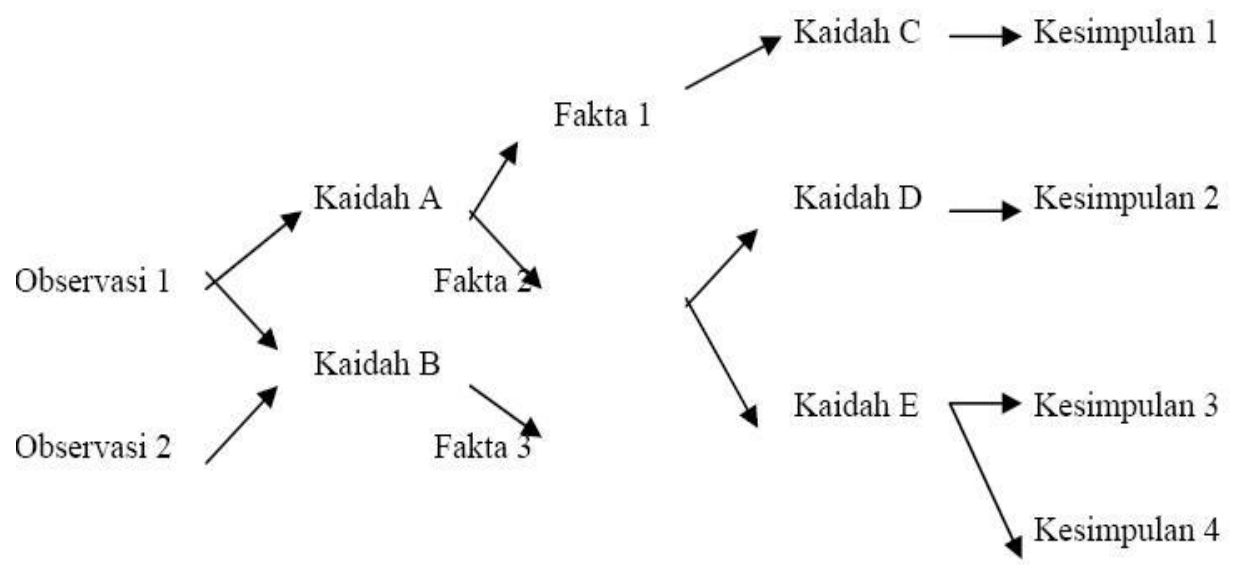

Gambar 1. Proses Forward Chaining (Sumber: Muhammad Arhami, 2005)

Terdapat tiga (3) macam penulusuran, yaitu Breadth-first search, Depth-first searc, dan Best-first search 
- Dept first search, melakukan penelusuran kaidah secara mendalam dari simpul akar bergerak turun ke tingkat dalam yang berurutan.

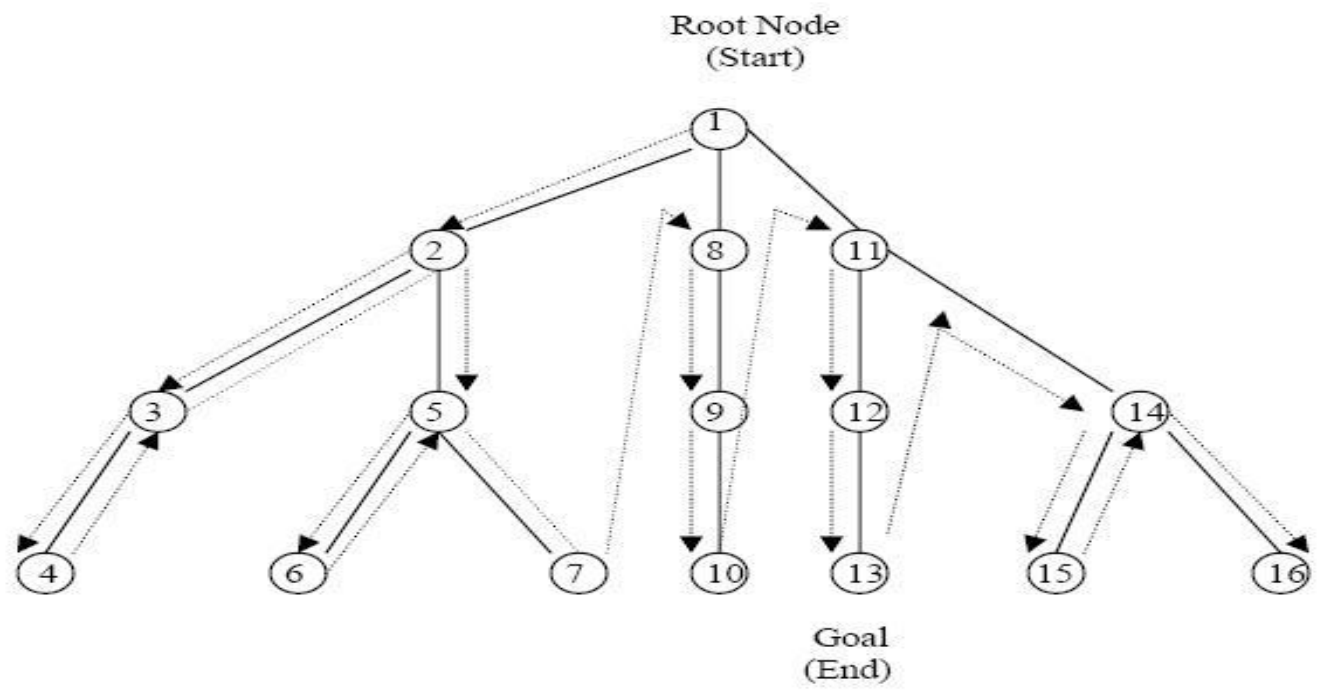

Gambar 2. Diagram Alir Penelusuran Depth First Search

- Breadth-first search, melakukan penelusuran dari simpul akar, simpul yang ada pada setiap tingkat akan diuji sebelum pindah ke tingkat selanjutnya.

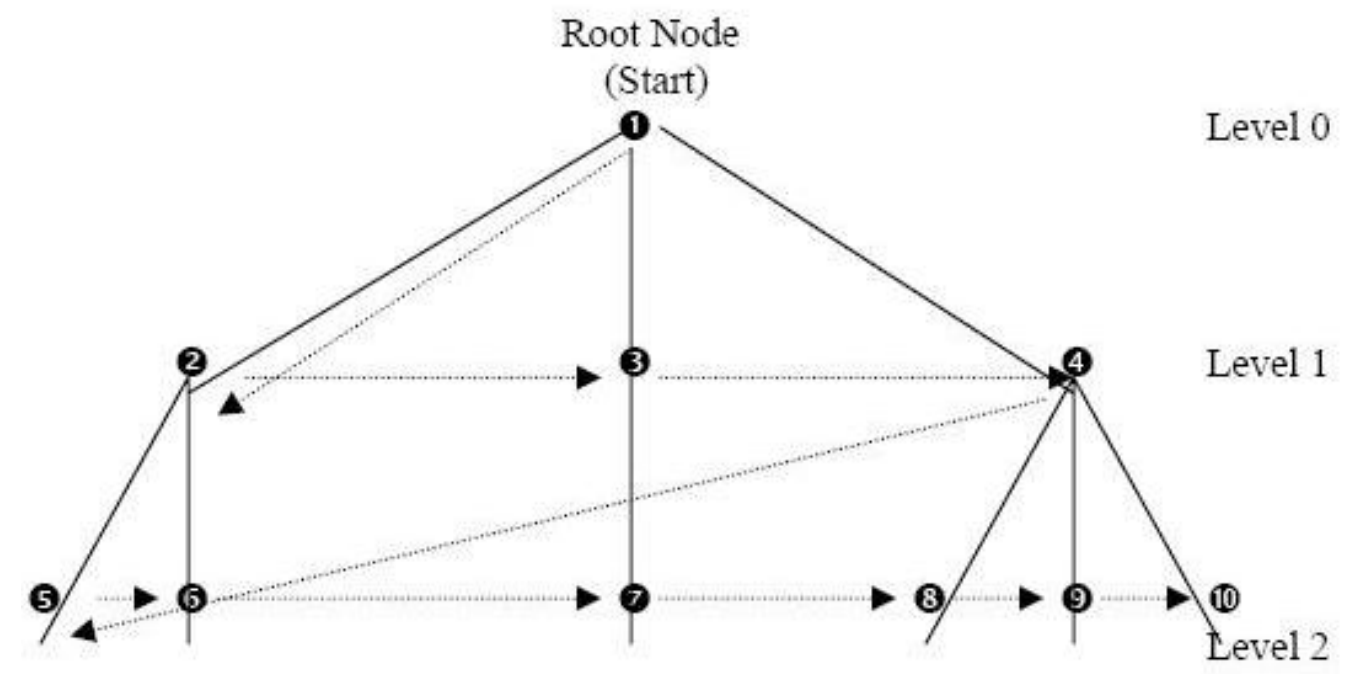

Gambar 3. Diagram Alir Penelusuran Breadth-first search (Sumber: Muhammad Arhami, 2005)

- Best-first search, bekerja dengan kombinasi kedua metode sebelumnya 


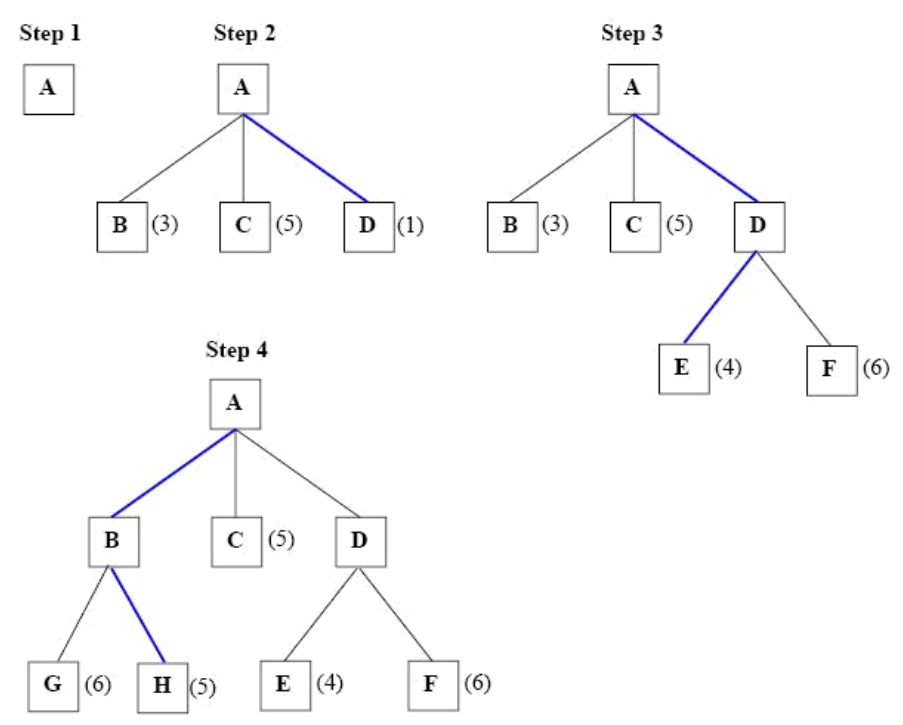

Gambar 4. Best-First Search

(Sumber: Muhammad Arhami, 2005)

\section{HASIL}

\subsection{Analisis Basis Pengetahuan}

A. Blok Diagram Area Permasalahan

Tujuan pembuatan blok diagram adalah untuk membatasi ruang lingkup permasalahan yang dibahas dengan mengetahui pokok bahasan pada domain yang lebih luas. Blok diagram ini bisa dilihat bahwa penyakit ayam yang dijadikan sebagai area permasalahan. Sedangkan yang di prototipekan hanyalah bagian dari domain permasalahan penyakit ayam yang disebabkan oleh virus dan bakteri, jamur, protozoa, dan kurang vitamin.

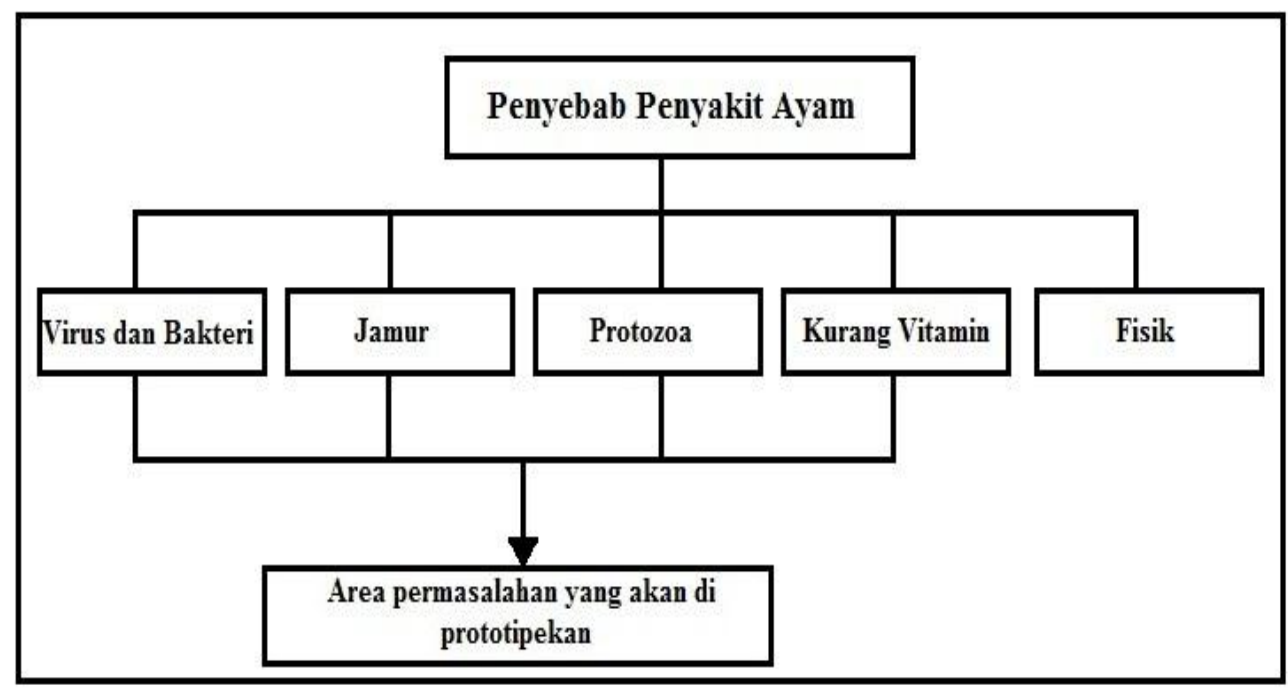

Gambar 5. Blok diagram area permasalahan 


\section{B. Blok Diagram Fokus Permasalahan}

Pada tahap ini terdapat permasalahan penyakit ayam yang terfokus pada gejala yang timbul pada sebagian organ tubuh ayam yang tampak secara fisik. Diagram blok fokus permasalahan berfungsi untuk menjelaskan situasi penentuan keputusan untuk mendiagnosa penyakit ayam berdasarkan klasifikasi gejala yang tampak secara fisik. Untuk menjelaskan jenis penyakit yang ada pada ayam, maka akan dibentuk blok diagram sub fokus permasalahan yang berdasarkan pada gejala yang tampak.

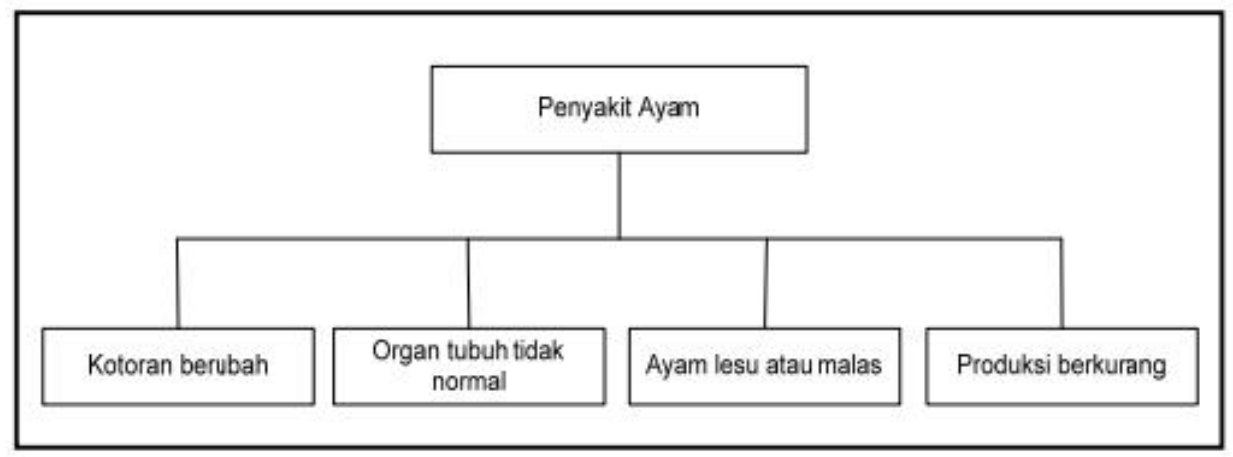

Gambar 6. Blok diagram fokus permasalahan

\section{Blok Diagram Faktor Kritis}

Pada gambar 3.3 merupakan blok diagram yang dipakai untuk menegaskan faktor kritis dalam area target keputusan yang akan dimodelkan. Gejala yang menjadi faktor kritis yang akan berjalan dalam pembuatan aplikasi ini adalah Gejala, gejala klinis yang terdapat dalam tubuh ayam, keadaan farm atau kandang ayam maupun pola prilaku ayam. Dari masukan gejala yang dirasa oleh pengguna akan digabungkan, maka akan didapatkan pencapaian hasil dari konsultasi yang berupa saran pencegahan dan pengobatan penyakit ayam tersebut. Contoh dari blok diagram faktor kritis ini adalah dari gejala pertama apabila terdapat gejala klinis seperti kulit pucat atau bengkak pada tubuh ayam, gejala kedua adalah keadaan kandang yang kurang baik, dan terakhir dari perilaku ayam yang tidak biasa seperti bergerombol pada sumber panas, maka dari gejala-gejala tersebut akan didapatkan analisa penyakit yang mungkin dapat terjadi pada ayam. Yang nantinya akan diberikan saran pencegahan dan pengobatan bagi ayam tersebut.

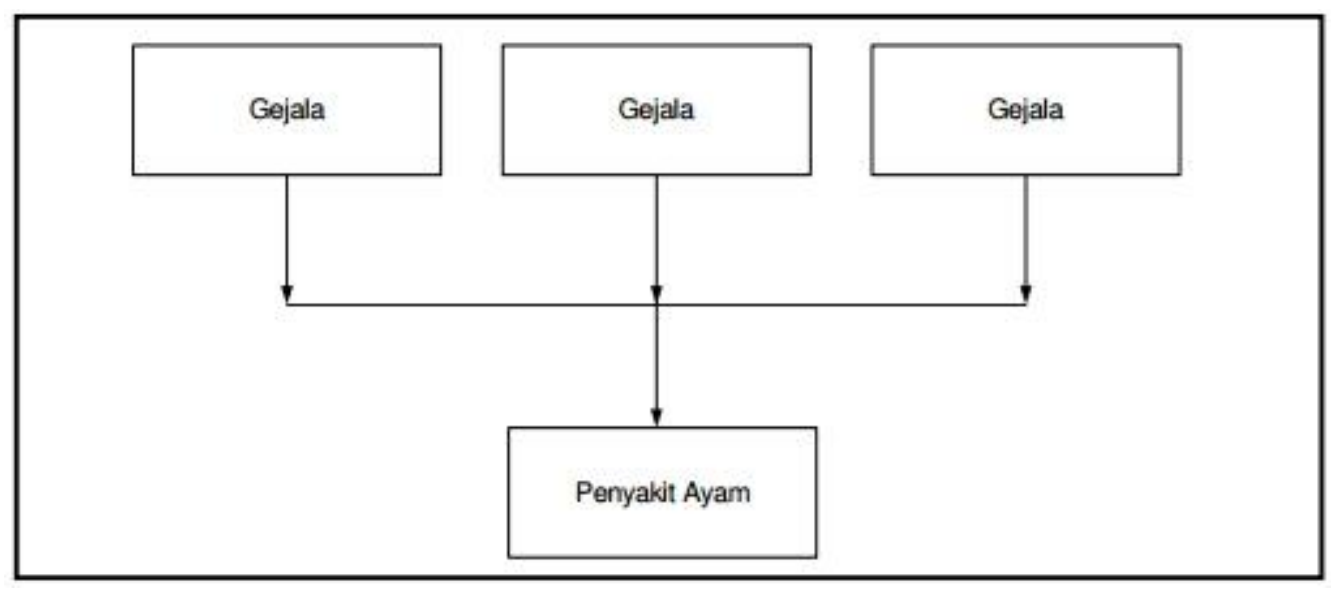

Gambar 7. Diagram Blok faktor kritis 


\subsection{Flowchart}

Flowchart program pada gambar 8 merupakan keseluruhan proses diagnosa penyakit pada ayam yang dilakukan oleh pengguna yaitu mulai dari proses input data pengguna, kemudian dilanjutkan ke proses diagnosa penyakit dengan memilih data gejala yang ditampilkan oleh sistem dan yang terakhir adalah proses hasil diagnosa.

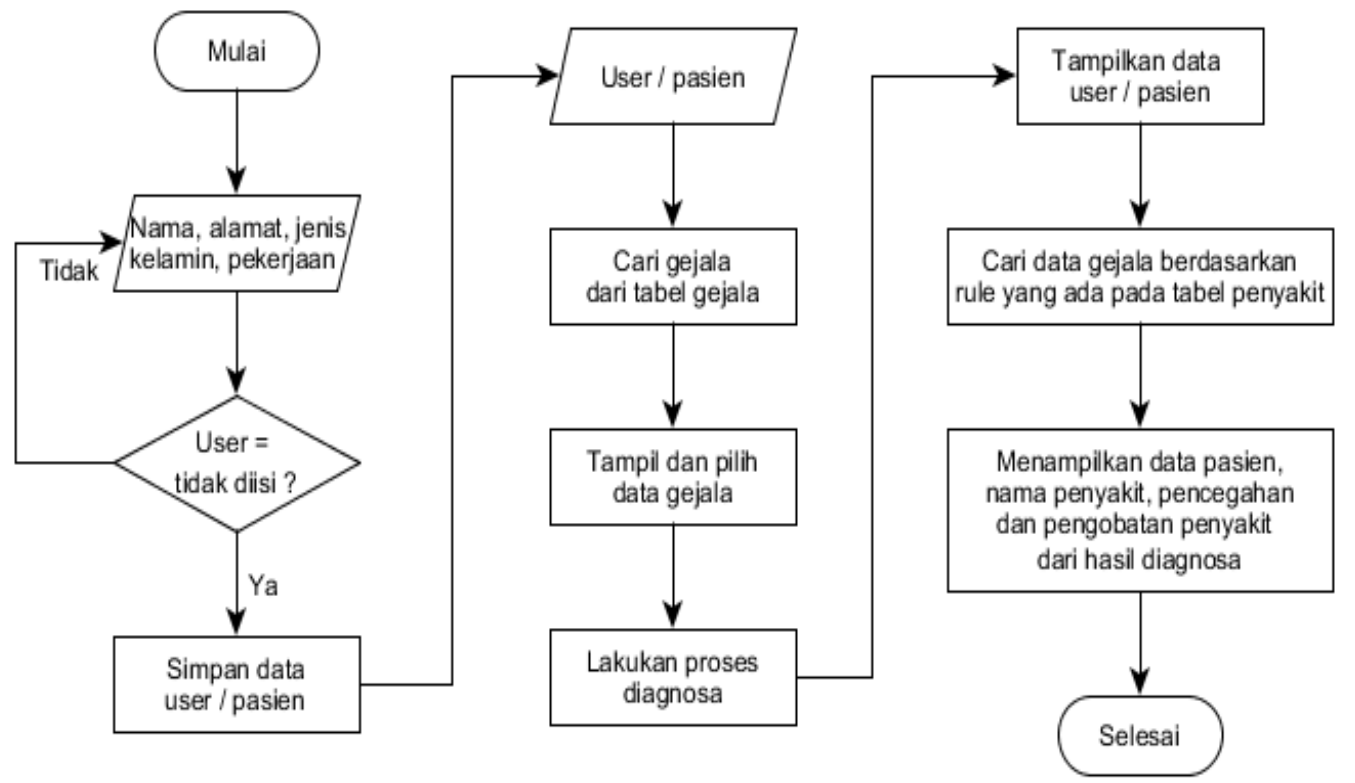

Gambar 8. Flowchart proses diagnosis penyakit ayam

\subsection{Analisis Sistem}

Proses pembuatan sistem ini memerlukan perangkat lunak pendukung, berikut ini adalah analisis kebutuhan non fungsional:

Hardware

- Processor : AMD A-300 APU Radeon HD Graphics $1.30 \mathrm{GHz}$

- RAM $: 2 \mathrm{~GB}$

- System Type : 32-bit Operating System

- Sistem Operasi : Windows 7 Ultimate

Software

- Macromedia Dreamweaver MX 2004

- Xampp v3.2.1

- Mozilla Firefox

\subsection{User Interface}

\section{A. Interface Data Penyakit}

Pada menu penyakit berisi sub menu untuk mengolah data penyakit yang berfungsi untuk memasukkan jenis penyakit-penyakit baru berserta pencegahan, dan pengobatannya, maupun mengubah dan menghapus data penyakit. Adapun interface sistemnya dapat dilihat pada gambar 9 dibawah ini : 


\begin{tabular}{|c|c|c|c|c|c|}
\hline Halaman Admin & & Nomor & Kode Penyakit & Nama Penyakit & Menu \\
\hline A Home & & 1 & P001 & Berak Kapur & Ubah | Hapus \\
\hline if Admin & v & 2 & P002 & Kolera Ayam & Ubah | Hapus \\
\hline & & 3 & $\mathrm{P} 003$ & Flu Burung & Ubah | Hapus \\
\hline & & 4 & P004 & Tetelo & Ubah | Hapus \\
\hline E Gejala & & 5 & P005 & Tipus Ayam & Ubah | Hapus \\
\hline$\equiv$ Data Aturan & & 6 & $\mathrm{P} 006$ & Berak Darah & Ubah | Hapus \\
\hline$\star$ Laporan & $\checkmark$ & 7 & P007 & Gumboro & Ubah | Hapus \\
\hline (t) Logout & & 8 & P008 & Salesma Ayam (Snot) & Ubah | Hapus \\
\hline & & 9 & P009 & Virus IB & Ubah | Hapus \\
\hline & & 10 & P010 & Penyakit Helikopter & Ubah | Hapus \\
\hline
\end{tabular}

Gambar 9. Interface data Penyakit

\section{B. Interface Data Gejala}

Didalam menu gejala berisi sub menu untuk mengolah data gejala yang berfungsi untuk memasukkan data gejala baru, maupun mengubah dan menghapus data gejala. Adapun desainya adalah sebagai berikut :

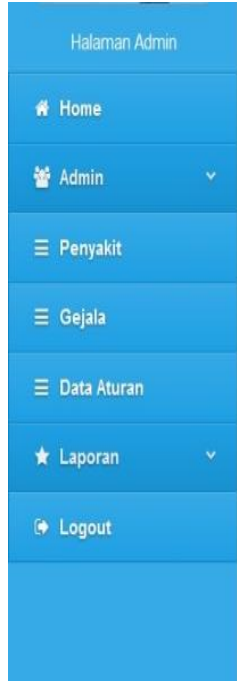

\begin{tabular}{|c|l|l|l|}
\hline Nomor & Kode Gejala & Nama Gejala & Ubah | Hapus \\
\hline 1 & 6001 & Nafsu makan berkurang & Ubah | Hapus \\
\hline 2 & 6002 & Nafas sesak/ megap-megap / mulut terbuka saat bernafas & Ubah | Hapus \\
\hline 3 & 6003 & Nafas ngorok & Ubah | Hapus \\
\hline 4 & 6004 & Kulit/ kepala pucat & Ubah | Hapus \\
\hline 5 & 6005 & Bersin-bersin & Ubah | Hapus \\
\hline 7 & 6006 & Batuk & Ubah | Hapus \\
\hline 8 & 6007 & Badan kurus / berat badan turun & Ubah | Hapus \\
\hline 9 & 6008 & Bulu kusam atau kusut & Ubah | Hapus \\
\hline 10 & 6010 & Diare & Ubah | Hapus \\
\hline
\end{tabular}

Gambar 10. Interface data Gejala

\section{Interface Diagnosis Penyakit}

Halaman diagnosa merupakan halaman inti dari sistem pakar diagnosa penyakit pada ayam ini terdapat pertanyaan bagi pengguna yang ingin melakukan proses diagnosa penyakit ayam diharuskan memilih gejala sesuai dengan gejala yang ada. Adapun interface halamannya adalah sebagai berikut : 


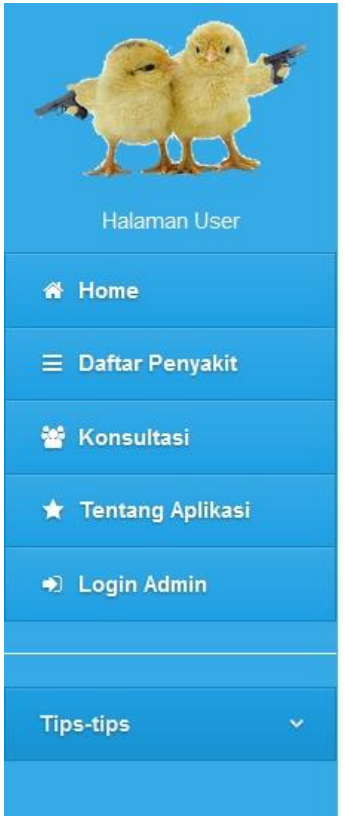

JAWABLAH PERTANYAAN BERIKUT :

Apakah Ayam Anda mengalami Kulit / kepala pucat[ G004 ] ?

- Benar $(Y A) \odot$ Salah (TIDAK)

Jawab

GEJALA YANG TERPILIH YA (BENAR)

[ G002 ] = Nafas sesak/ megap-megap / mulut terbuka saat bernafas

PENYAKIT YANG MUNGKIN TERSERANG

[ P011 ] = Virus ILT (herpes)

$[\mathrm{P} 012]=$ Mareks

$[$ P025 ] = Infeksi Pneumovirus

\section{Gambar 11. Interface Diagnosis Penyakit}

\section{Interface Hasil Diagnosis}

Halaman hasil diagnosa merupakan halaman yang memberikan informasi hasil dari inputan pengguna yang melakukan proses diagnosa. Menampilkan informasi penyakit, solusi pencegahan dan pengobatan serta data dari pengguna itu sendiri. Adapun interface halamannya adalah sebagai berikut :

\begin{tabular}{|c|c|}
\hline \multicolumn{2}{|c|}{ HASIL ANALISA PENYAKIT AYAM } \\
\hline \multicolumn{2}{|l|}{ DATA PASIEN : } \\
\hline Nama & Nanang \\
\hline Kelamin & Pria \\
\hline Alamat & Plaosan \\
\hline Pekerjaan & Wiraswasta \\
\hline \multicolumn{2}{|c|}{ HASIL ANALISA TERAKHIR : } \\
\hline Nama Penyakit & P008 | Salesma Ayam (Snot) \\
\hline Gejala & $\begin{array}{l}\text { 1. Mata cenderung menutup } \\
\text { 2. Pembengkakan dari sinus dan mata } \\
\text { 3. Keluar nanah dari mata dan bau } \\
\text { 4. Keluar cairan dari hidung } \\
\text { 5. Bersin-bersin } \\
\text { 6. Kelopak mata kemerahan } \\
\text { 7. Produksi telur menurun }\end{array}$ \\
\hline Keterangan & $\begin{array}{l}\text { Penyakit Infectious Coryza disebut juga Infectious Cold, Snot, Rhinitis, Roup atau yang populer disebut salesma ayam.Penyakit ini sering timbul terutama pada saat } \\
\text { hujan kelembaban tinggi. Disebabkan oleh Bakteri Haemophylus Paragallinarum }\end{array}$ \\
\hline Solusi & $\begin{array}{l}\text { Berikan Amphyvitacol produksi vaksindo. Atau dapat diberikan Vibravet dengan takaran } 4 \text { gram dicampur } 1 \text { liter air minum, diberikan } 4-5 \text { hari. Jika kondisi ayam sudah } \\
\text { parah dapat diberikan obat secara suntikan Sulfamix dengan dosis } 0.4 \mathrm{cc} / \mathrm{kg} \text { pada ayam yang terkena penyakit }\end{array}$ \\
\hline
\end{tabular}

Gambar 12. Interface hasil diagnosis 


\section{KESIMPULAN}

Berdasarkan hasil pengujian, aplikasi Perancangan dan Implementasi Sistem Penentuan Penyakit Pada Ayam Berdasarkan Gejala Yang Timbul ini cukup membantu memberikan pengetahuan pengguna tentang penyakit ayam berdasarkan diagnosa yang telah dilakukan. Mesin penelusuran atau Inference engine bekerja dengan baik, sesuai dengan rule atau aturan yang telah diprogramkan sebelumnya. Adanya pengembangan informasi yang diperlukan untuk membantu dalam melakukan identifikasi penyakit ayam yang dapat dijadikan media yang tepat untuk penggunanya dalam menerima informasi yang akurat, terpercaya, dan memiliki nilai yang efektif dan juga efisien bagi pengguna. Pengetahuan Sistem Penentuanm Penyakit Pada Ayam Berdasarkan Gejala Yang Timbul dapat semakin diperkaya dengan penambahan gejala yang diberikan, agar dapat memberikan penjelasan informasi kepada pengguna yang lebih komplek.

\section{DAFTAR PUSTAKA}

[1] Rich, Elaine dan Knight, Kevin. 1991. Artificial Intelligence. McGraw-Hill Inc, New York.

[2] Martin, J., Oxman, S. 1998. Building Expert System a Tutorial. Prentince Hall, New Jersey.

[3] Arhami, M. 2005. Konsep Dasar Sistem Pakar. Andi Publiser, Yogyakarta.

[4] Hayadi, B. H., Rukun, K., Wulansari, R. E., Herawan, T., Dahliyusmanto, Setaiwan, D., Safril. 2017. Expert System of Quail Disease Diagnosis Using Forward Chaining Method, Indonesian Journal of Electrical Engineering and Computer Science, vol. 05, No. 1. 